\title{
The Influence of Age Cohorts and Social Networks on the Language Choices of the Non-Indigenous Tamil Minority in Kuching, Sarawak, Malaysia
}

\author{
*PONMALAR N. ALAGAPPAR ${ }^{1}$ \\ CAESAR DEALWIS ${ }^{2}$ \\ MAYA KHEMLANI DAVID 3,4 \\ ${ }^{1}$ Centre for the Initiation of Talent and Industrial Training (CITra), \\ University of Malaya, 50603 Kuala Lumpur, Malaysia \\ ${ }^{2}$ Academy of Language Studies, Universiti Teknologi MARA Sarawak, Meranek Road, \\ 94300 Kota Samarahan, Sarawak, Malaysia \\ ${ }^{3}$ Faculty of Language and Linguistic, University of Malaya, 50603 Kuala Lumpur, Malaysia \\ Current affiliation: \\ ${ }^{4}$ London College of Clinical Hypnosis, No. 9 Jalan 16/11, Pusat Perdagangan Phileo Damansara, \\ 46350 Petaling Jaya, Selangor, Malaysia \\ *Corresponding author: ponmalar.a@um.edu.my
}

Published online: 20 April 2018

To cite this article: Alagappar, P.N., Dealwis, C. and David, M.K. 2018. The influence of age cohorts and social networks on the language choices of the non-indigenous Tamil minority in Kuching, Sarawak, Malaysia. KEMANUSIAAN the Asian Journal of Humanities 25(1): 69-93, https://doi.org/10.21315/kajh2018.25.1.4

To link to this article: https://doi.org/10.21315/kajh2018.25.1.4

\begin{abstract}
This paper reports on the application of age cohorts to the theory of social networks in a study of language choices of Tamil city dwellers in Kuching, Sarawak located on the island of Borneo. This study, which adopts Milroy's (1980) social networks, focuses mainly on code choices made in the spoken discourse of multilingual Tamils of different age cohorts. Our analysis of data gathered from a one-shot survey and supported by face-to-face interviews shows variations in code choices by age cohort. Code selections within and across the different age cohorts in the home and friendship domains denote the influence of age and social networks among minority Tamils.
\end{abstract}

Keywords and phrases: language choices, social networks, code choice, age cohorts, Tamils of Kuching

\section{Introduction}

Language choice has been of interest to many researchers and especially in reference to bilingual and multilingual speech communities where there are choices 
not only between varieties of a language but also between different languages and dialects. Researchers such as Ferguson (1959), Fishman (1972), Wallwork (1978), Gumperz (1982) and Heller (1988) have studied language use with a focus on language choice. According to Fasold (1984), language choice involves codeshifting, code-mixing and code-switching. David $(2001,101)$ defines code-mixing as the use of not only single lexical items but also mixing at the phrase or clause level for the same sentence from another code; code-switching involves the use of two languages while code shifting involves the use of different codes in different turns.

Language users tend to use code(s) depending on whom they interact with and this can be captured in specific reference to their age cohorts. The relationship between language choices, social networks and age cohorts has been a primary research focus of sociolinguists interested in processes of language variation and language shifting. Most of such studies on Malaysia have involved quantitative analyses (surveys) supported by qualitative analyses (transcriptions of real-time conversations, interviews and observations) (David et al. 2009). The present study focuses on age cohort linguistic choices whereby the patterns of choices of the Tamil community in Kuching are related to the age cohorts of speakers and those with whom they interact.

In demonstrating the phenomenon of language choice, non-indigenous minority Indian communities in Malaysia pose a different challenge than indigenous communities such as the Iban, Bidayuh and Kadazan. Non-indigenous communities can shift to the use of a dominant language when there are obvious advantages to doing so and when perceived as favourable to the community concerned. Indians who have converted to Islam are being assimilated into Malay cultural norms, assuming Malay identity and living among the Malays in Kuching to enjoy privileges accorded to the Malays, who are also known as the bumiputeras (Dealwis and David 2010).

Much of the immigrant Indian population in Malaysia established in minority communities originates from India but arrived in Malaya (now Malaysia) through different migratory routes [Sindhis in Malaya in David (1999); Malayalees in Malaya in Nambiar (2007); Telegus in Sarawak in David and Dealwis (2006)]. These immigrants came with different political, cultural and economic histories and taken as a whole, Indian immigrants of the 1930s displayed a total lack of homogeneity as a community, causing outside observers, including such eminent and detached Western scholars as Emerson (1973) and Mills (1941), to conclude that the Indian community in Malaya as a whole was transient and apolitical (Tate 2008, 21-23). 
The purpose of the present study in relation to current related research is to determine the language choices of different age cohorts of minority Kuching Tamils and to conclude whether close and dense networks would also lead them to use Tamil more with one another.

Age cohorts or age distribution numbers are often used to language change and whether language shifts have occurred in an immigrant community (Nambiar 2007). Clyne (1976) and Demos (1988) have also identified age and differences in language proficiency as having a significant impact on language maintenance or shifts in an immigrant community. However, conclusions focusing on age cohorts based on one-shot surveys can be misleading as demonstrated by a case study of French-English bilingualism in Montreal (Lieberson 1965). This is an important consideration for our study, as Tamils in Kuching also represent an immigrant community; therefore, a semi-structured interview was conducted to validate the one-shot survey.

When data are gathered at only a single point in time, i.e., one-shot survey, Lieberson (1965) suggested that a researcher can ask "retrospective questions" of whether the data provide a means for determining longitudinal change (asking not only about present use patterns but also about past patterns of usage). According to Saxena (2003), intergenerational change can be studied by comparing the language choices of young adults with retrospective answers given by those who are somewhat older. This is related to the subtopic of age cohorts explored in this study, as Tamils who born in Sarawak received their education in Sarawak and have different attitudes towards their heritage language and towards the national language of their host country.

Gal (1979) and Milroy (1980) have especially used social network theory to explain their findings of studies of language variations and language change in Austria and Belfast, respectively. Based on the idea of social networks, the authors show that people are to a great extent reliant on the ways that they use language with people with whom they interact and especially in everyday encounters. The social network concept utilises the notion of a field visualised as a set of nodes joined by lines in demonstrating the relationship between individuals, i.e., network density and multiplexity. Individuals are denoted by nodes and links or connections between these individuals are signified by lines. The model is illustrated in Figure 1.

A is directly related to $\mathrm{B}, \mathrm{C}, \mathrm{D}, \mathrm{E}, \mathrm{F}$ and $\mathrm{H}$, though $\mathrm{D}$ is only related to $\mathrm{A}$ and $\mathrm{G}$ while $\mathrm{B}$ is related to $\mathrm{A}, \mathrm{E}$ and $\mathrm{F}$ and so on. The model shows how social networks shape a web of transactions that shape the quality of everyday life, thus involving people in 
rights and responsibilities towards one another (Downes 1984, 96-97). Multiplex networks imply that within a network there may be more than one transactional basis for social relationships. For example, the same individuals can be linked by employment, kinship, etc. Network density denotes the number of relationships an individual has with other individuals. A high-density multiplex network manifests when individuals are in contact with one another freely (i.e., friendship), and it is through this system of networking that the maintenance of language occurs (David 2005). General norms for the enforcement of language maintenance are based on the strength of a social network itself (Milroy 1980).

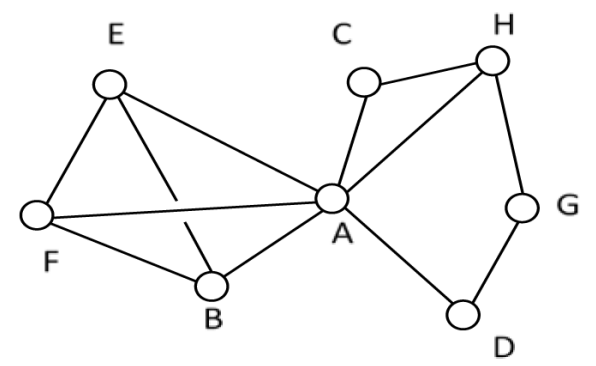

Figure 1. An example of a social network

Source: David $(2005,154)$

Milroy (1987) contends that language maintenance is more grounded when a community has a strong and solid network. The importance of social network theory in envisaging language maintenance or shifts can be observed from a study of language maintenance in the United Kingdom (Milroy 1987). In social network analysis, language is likewise regarded as a tool for network maintenance. Studies of Malaysian Sindhis (David 2003), Punjabis (David, Naji and Kaur 2003), Bengalis (Mukherjee 2003), Malayalees (Govindasamy and Nambiar 2002), Tamil Chittys (Sankar 2004) and Portuguese in Malacca (David and Noor 1999) have shown that while these communities are based on strong, dense and multiplex networks, a shift has occurred due to the use of English as the international language.

However, this shift has not brought about a break in ties, and communities have retained close networks by maintaining other ethnic and cultural norms [see David (1999) on how the Malaysian Sindhis have upheld their ethnic and cultural norms of discourse through the English phrases that they use]. These results alert us to the perils of accommodating studies from the West by assuming that similar principles would apply in multilingual settings such as Malaysia (David 2006). 


\section{Kuching Tamils: A Brief Historical Background}

Sarawak's early contact with Indians occurred largely due to the mining of gold, which was found in regions stretching from Bau in Sarawak to Sambas and Montrado in West Kalimantan. The Sarawak River Delta operated as the focal point for trade [Chang (2002) as cited in David (2009)]. There are no statistics on the number of Tamils who first came to Sarawak in 1900 or on those who returned to India before Sarawak became part of Malaysia in 1963. However, the early Tamils were generally poor, and as in Peninsular Malaysia, Tamil immigrants from India were Hindus and belonged to the lower castes (Tate 2008, 1-3).

Today, together with the other Indians, the community's role and contributions to the state of Sarawak and its development have far exceeded, proportionately speaking, its size within Sarawak's population of 2.1 million (Audrey, 2008). The Indians form the second largest immigrant community in Sarawak after the Chinese. The Tamil community in Sarawak comprises of 3,267 individuals of a total Indian population of 5,210 (Department of Statistics Malaysia 2009). They make up the largest Indian community in Sarawak followed by the Malayalees and the Telegus. The three Brooke Rajahs expounded similar notions of the economic development of Sarawak. When Rajah Charles Brooke (1868-1917) mapped out strategies to render agriculture - the main economic activity in Sarawak with the introduction of new crops, i.e., coffee, tea, gambier, pepper, cocoa, tobacco, and a liberal land policy - the Tamils were brought in to work as labourers on tea and coffee plantations of the White Rajah; this was further implemented by Rajah Vyner Brooke (1917-1946). During the colonial administration (1946-1963), the Indians were brought in to work in the Public Works Department in Kuching.

The first Tamil settlement was located at Gunung Serapi (Mount Serapi) in Matang. A number of Tamils had married outside of their own Indian linguistic group and had also contracted marriages with local people such as the Dayaks, Orang Ulus and Malays. Today, the Tamils can be found in various parts of Kuching, namely, along Green Road, Nanas Road, Sungai Maong, Rubber Road, Matang, Batu Kawa, Sekama, Batu Lintang, Airport Road and Mile 12 Kuching-Serian Road (David, Dealwis and Alagappar 2011).

Local Tamils who have married Malays are Muslims and have identified themselves as Malays (David and Dealwis 2009). They are referred to as Tulcans by the Hindu Tamils and are mostly involved in the textile and food businesses. They live in predominantly Malay residential areas in the city of Kuching while those who have married Dayaks have assimilated Dayak and Indian cultural norms at home 
and reside in both urban and rural areas (David and Dealwis 2009). Today, the Kuching Tamils are mostly average and below average income earners, working in government departments, and they practise a number of different faiths, including Hinduism, Christianity and Islam. The majority, however, are Hindus. There are two Hindu temples in the city of Kuching, and the majority of Tamil Hindus celebrate Thaipusam and Deepavali.

\section{Method}

In total, 160 respondents were sampled in via convenience sampling. However, only 119 questionnaires had complete information and were useable. Data obtained from the questionnaires were analysed to establish an overview of the respondents' educational backgrounds, languages first learnt and social networks. The respondents were selected using the snowball technique, i.e., by us being introduced by friends and through contacts made at Hindu temples and gatherings. All of the respondents were born in Kuching and were divided into the following age cohorts: 12-21 years, 22-39 years, 40-59 years and 60 years and above. A total of 58 respondents were interviewed. Of these respondents, 15 were 12-21 years of age, 20 were $22-39$ years of age, 15 were $40-59$ years of age and 8 were 60 years of age and above.

Our rationale for using both quantitative and qualitative methods was to triangulate the data and to strengthen findings made from the data collected. Data gathered from one instrument differed from those derived from the other, as questions asked during the semi-structured interviews revealed the attitudes and perceptions of the respondents to complement the quantitative findings. The city of Kuching, Sarawak was selected as the study area.

\section{Findings}

\section{Demographic variables}

Table 1 shows that the 12-21 and 22-39 year age cohorts present similar "verbal repertoires" [namely, Tamil, Bahasa Melayu (formal Malay), Sarawak Malay (a local Malay dialect) and English]. The 40-59 year age cohort does not speak Sarawak Malay, and these individuals are proficient in Hokkien Chinese. Informal interviews conducted with the 40-59 year age cohort show that their homes and schools are located in Chinese areas (e.g., Batu Lintang, Batu Satu, Rubber Road, Green Road and Palm Road), requiring them to learn Hokkien to assimilate with the Chinese living in their schools and neighbourhoods. Respondents of the 12-29 and 22-39 year age cohorts live in the following areas: Batu Kawa, Matang, 
Airport Road and Mile 12 Kuching-Serian Road. In these areas, schools have more Dayak and Malay students. Respondents of the 60 years and above age cohort speak Tamil and Bahasa Melayu and have less education compared to the younger age groups who are better educated.

Table 1. Age cohorts, highest academic attainment and common languages spoken by members

\begin{tabular}{|c|c|c|c|}
\hline Age cohort & $\begin{array}{c}\text { No. of } \\
\text { respondents }\end{array}$ & $\begin{array}{c}\text { Highest level of education/ } \\
\text { No. of respondents }\end{array}$ & $\begin{array}{l}\text { Languages spoken by } \\
\text { members of this group }\end{array}$ \\
\hline $12-21$ years & 22 & $\begin{array}{l}\text { First degree: } 6 \\
\text { Diploma: } 7 \\
\text { Certificate: } 6 \\
\text { Secondary school: } 3\end{array}$ & $\begin{array}{l}\text { Tamil } \\
\text { Bahasa Melayu } \\
\text { Sarawak Malay } \\
\text { English }\end{array}$ \\
\hline $22-39$ years & 63 & $\begin{array}{l}\text { First degree: } 8 \\
\text { Diploma: } 17 \\
\text { Certificate: } 18 \\
\text { Secondary school: } 20\end{array}$ & $\begin{array}{l}\text { Tamil } \\
\text { Bahasa Melayu } \\
\text { Sarawak Malay } \\
\text { English }\end{array}$ \\
\hline $40-59$ years & 29 & $\begin{array}{l}\text { First degree: } 1 \\
\text { Diploma: } 3 \\
\text { Certificate: } 6 \\
\text { Secondary school: } 19\end{array}$ & $\begin{array}{l}\text { Tamil } \\
\text { Bahasa Melayu } \\
\text { English } \\
\text { Hokkien Chinese }\end{array}$ \\
\hline 60 years and above & 5 & Primary education: 5 & $\begin{array}{l}\text { Tamil } \\
\text { Bazaar Malay (pidgin) }\end{array}$ \\
\hline
\end{tabular}

\section{Language first learnt}

All of the respondents of the 60 years and above age cohort learnt Tamil as their first language. Their parents were brought to Kuching from Tamil Nadu as labourers during the "White Rajahs" era, and as new migrants they did not know the local languages. Therefore, the first language that they learnt was Tamil (see Appendix - Table A).

Overall, $92.1 \%$ and $93.1 \%$ of the respondents of the $22-39$ and $40-59$ year age cohorts, respectively, learnt Tamil as their first language, as their parents spoke to them in Tamil. The respondents' parents were not highly educated and lacked exposure to the English language. Tamil is also the first language for most (63.4\%) of the respondents of the 12-21 year age cohort, though 36.4\% learnt English as their first language. Respondent 16 (male, 17 years old) stated: "My parents were English educated and they wanted us to speak good English so that we could go overseas to study and work later". The interview data show that language utility influences language use at home. 


\section{Kinship and friendship networks}

Social networks are categorised as "average, high density, or very high density" based on criteria proposed by Milroy (1980). In this study, the criteria for social networks are such that when members of the minority Kuching Tamil community socialise only among themselves using Tamil and knowing each other very well, this is considered a very high density social network. However, when members of the community attend events organised by the community and socialise with other ethnic groups, speaking other languages apart from Tamil, then this is referred to a high density social network. An average density social network refers to members of the Kuching Tamil community who seldom attend Tamil events organised by the community and who socialise more with other ethnic groups.

The social networks of Tamils residing in Kuching display a strong pattern of relationships (Table 2). All of the respondents of this study stated that they were related to one another either through kinship or marriage. The Tamils in Kuching maintain high density multiplex networks that are further reinforced by the Hindu religion. This was established from the collected data, i.e., they meet every weekend at the Sri Mahariaman Temple on Ban Hock Road and attend weddings, funerals, festivals and celebrations such as Deepavali, Thaipusam, Ponggal and other activities organised by the Kuching Indian Association.

Respondents of the older age cohorts (namely, those 40-59 years of age and 60 years of age and above) maintain a very high density social network of Tamil kinship and friendship compared to the respondents of 12-21 and 22-39 years of age. This was established by the fact that they socialised only with Tamils, as they have known each other from youth.

Respondent 66 (male, 55 years old) stated: "If I don't attend wedding functions or any function, people will call up to ask me why ... always I go, rain no rain. Even people children I don't know, I go. I don't very like also I go, if not people will talk. No good for my children".

Table 2. Members of Tamil in social network linked by kinship and friendship

\begin{tabular}{lll}
\hline Age cohort & Kinship & Friendship \\
\hline $12-21$ years (22 respondents) & High density & Average density \\
$22-39$ years (63 respondents) & High density & High density \\
$40-59$ years (29 respondents) & Very high density & Very high density \\
60 years and above (3 respondents) & Very high density & Very high density \\
\hline
\end{tabular}


On the other hand, respondent 19 (male, 23 years old) stated: "My mother goes for weddings regularly. My father always goes for funerals. I sometimes go for either. I don't know many of them as compared to my parents. Sometimes I go for weddings just because of the good food and check out the pretty girls in saris".

\section{Language in the home domain}

The data show the respondents' consistency in choosing the language of their grandmothers or grandfathers (see Appendix - Table B). Respondents of the 12-21 year age cohort tend to use the Tamil language as a standalone language less than respondents of the other age cohorts. A total of $36.4 \%$ of the respondents of the 12-21 year age cohort chose Bahasa Melayu when asked which language they used with their grandparents. Most of these respondents are not proficient in Tamil as their first language is English.

Respondent 5 (male, 18 years old) stated: "My mother is a Dayak and she speaks Malay with us at home. My father who is a Tamil speaks Tamil with us, and I can speak a little Tamil but I am not fluent". On the other hand, some younger members of the community who despite not being the offspring of a mixed union have shifted to using English in the home domain. Respondent 11 (female, 13 years old) stated: "Both of my parents are Tamils but we speak more English at home. I speak Tamil mixed with Malay with my grandparents".

Respondents were also asked to describe language choices made when communicating with their parents. When communicating with their mothers, the vast majority (93.1\% and 100\%) of respondents of the 40-59 years of age and 60 years of age and above cohorts, respectively, use standalone Tamil. Respondent 49 (male, 52 years old) stated: "Of course I speak Tamil to both of my parents. That's our language and the only language my parents wanted us to use at home".

However, only $40.9 \%$ of respondents of the $12-21$ year age cohort use standalone Tamil with their mothers and $27.3 \%$ use Tamil with their fathers. This also seemed to be the case for the $22-39$ year age cohort, with $57.1 \%$ using standalone Tamil with their mothers and with $49.2 \%$ using Tamil with the fathers. This indicates a shift away from the use of the heritage language, as $35.4 \%$ of the respondents of the 12-21 year age cohort choose to use standalone English with their mothers while $45.5 \%$ use Tamil with their fathers. Due to a lack of proficiency in Tamil, respondents of the 12-21 year age cohort also use a code-switched pattern of Tamil and English. According to our interviews with respondents of the 12-21 year age cohort, the use of the heritage language has declined among the younger age cohorts, and only the older age cohorts tend to use Tamil with their parents. 
The third aspect of the home domain involves investigating language choices made with siblings (see Appendix - Table B). The results show that approximately 50\% of those of the 12-21 year age cohort use English with their older and younger siblings followed by $36.4 \%$ who using code-switching between Tamil and English. However, $4.5 \%$ of the respondents of the 12-21 year age cohort speak Bahasa Melayu with their younger siblings.

A corresponding decline in the use of the heritage language is observed with a decrease in age. Those of the 22-39 (38.1\%) year age cohort use standalone Tamil with their older and younger siblings and $49.2 \%$ code-switch between Tamil and English. Respondent 16 (female, 20 years old) stated: "When speaking to my sisters, we mix all the time. After all, there are many terms, especially those related to sciences and technology, that are in English". Standalone Tamil language use is still the dominant choice for those aged $40-59$ years of age and 60 years of age and above.

\section{Language used with visitors}

The majority (59.1\%) of those of the 12-21 year age cohort use a code-switched pattern of more Tamil with less English with their Tamil visitors (see Appendix Table C). Respondent 21 (male, 18 years old) stated: "I mix because it's fashionable and it sounds more modern and educated. Many words in Tamil are unknown, although both my parents are Tamil".

This finding is followed by $4.5 \%$ and $36.4 \%$ of the respondents of the $12-21$ year age cohort who respectively speak standalone Tamil and English, respectively, with their Tamil visitors. When speaking to their Telegu and Malayalee visitors, standalone English is the dominant language used by $63.6 \%$ of the $12-21$ year age cohort followed by $31.9 \%$ who code-switch between Tamil and English. It should be noted that the still smaller minorities of Telegus and Malayalees tend to understand Tamil, as Tamils form the majority of the Indian community in Kuching.

The majority (47.7\%) of those of the 22-39 year age cohort use a code-switching pattern of more Tamil with less English followed by $44.4 \%$ who speak standalone Tamil with their Tamil visitors. When speaking to their Telegu and Malayalee visitors, $39.7 \%$ of the $22-39$ year age cohort uses standalone Tamil followed by $34.9 \%$ who speak standalone English and another 20.6\% who use code-switching between Tamil and English. 
The majority (82.8\%) of those of the 40-59 year age cohort use standalone Tamil with their Tamil visitors followed by $10.3 \%$ who code-switch between Tamil and English and 6.9\% who use standalone English with their Tamil visitors. When speaking to their Telegu and Malayalee visitors, $37.9 \%$ of the $40-59$ year age cohort code-switch between Tamil and English followed by $34.5 \%$ who use standalone Tamil and $17.2 \%$ who use standalone English. All of the respondents of 60 years of age and above speak standalone Tamil with their Tamil visitors and code-switch between Tamil and English when speaking with their Telegu and Malayalee visitors.

\section{Language in the religious domain}

This section describes language choices made by the respondents at places of worship (see Appendix - Table D). In Hindu temples, respondents who are 60 years of age and above use standalone Tamil when speaking to fellow Tamils of all age cohorts. However, $45.5 \%$ of the respondents of the 12-22 year age cohort stated that when speaking with Tamils of the same age, they code-switch between using Tamil and English followed by 36.4\% who speak standalone English, 13.6\% who speak standalone Tamil and another $4.5 \%$ who code-switch between Tamil and Bahasa Melayu.

The percentage of respondents using standalone Tamil who are of the 22-39 year age cohort is lower, i.e., $55.6 \%$, than that of the $40-59$ year age group $(89.7 \%)$. Approximately $28.6 \%$ of the respondents of the 22-39 year age cohort stated they use a code-switching pattern involving more Tamil and less English. The findings also indicate a shift away from the heritage language during social interactions in temples among the younger age cohorts. Respondent 11 (male, 45 years old) stated: "I speak Tamil in the temple because all of my friends do the same and we feel very close. However, I see the younger boys and girls mix Tamil with English. I think they already have a Western influence".

It should be noted that $35.3 \%$ and $9.5 \%$ of the respondents of the $12-21$ and 22-39 year age cohorts, respectively, stated that they speak standalone English with fellow Tamilians of other age cohorts in temples. Respondent 13 (male, 23 years old) stated: "I speak English because the uncle who I always talk to at the temple is educated and likes to speak in English. Anyway, I feel more comfortable speaking in English with him".

Only $27.3 \%, 31.7 \%$ and $60.9 \%$ of the respondents of the $12-21,22-39$ and 40-59 year age cohorts, respectively, stated that they used standalone Tamil when speaking to individuals of other age cohorts at temples. Approximately 
$37.4 \%, 47.6 \%$ and $20.7 \%$ of the respondents of the $12-21$ year, $22-39$ year and 40-59 year age cohorts, respectively, stated that they used a code-switching patterns involving more Tamil and less English when speaking to individuals of other age cohorts. It is interesting to note that Bahasa Melayu is used by $6.9 \%$ as a standalone language by those of the 40-59 year age cohort when speaking to Tamils of other ages. All of the respondents of 60 years and above speak standalone Tamil with all age cohorts in temples. Respondent 63 (male, 62 years old) stated: "The children nowadays don't speak a lot of Tamil. I hear them mixing. Not my generation. We all speak Tamil only".

In discussing religious matters, the younger age cohorts of 12-21 years have opted to use less Tamil than older age cohorts. A total of $45.5 \%$ of individuals of the 12-21 year age cohort stated that they used standalone Tamil compared to $85.7 \%$ and $93.1 \%$ of the respondents of the $22-39$ and $40-59$ year age cohorts, respectively, who stated that they use standalone Tamil when discussing religious matters. In contrast, $100 \%$ of the respondents of 60 years of age and above stated that they use only standalone Tamil when discussing religious matters.

A large percentage, a $36.4 \%$ of the respondents of the 12-21 year age cohort compared to $6.3 \%$ and $3.4 \%$ of the respondents of the 22-39 and $40-59$ year age cohorts, respectively, stated that they use English to discuss religious matters. In addition, $13.6 \%$ and $4.8 \%$ of the respondents of the $12-21$ and $22-39$ year age cohorts, respectively, stated that they prefer to code-switch by using more Tamil with less English when discussing religious matters. We also found that $4.5 \%$, $3.2 \%$ and $3.4 \%$ of the respondents of the $12-21,22-39$ and $40-59$ year age cohorts, respectively, stated that they use Bahasa Melayu to discuss religious matters.

Generally, English and Bahasa Melayu seem to be more commonly used by the younger age cohorts due to the medium of instruction used in schools. Respondent 44 (female, 27 years old) stated: "I feel more comfortable with Tamil at home. At the temple when discussing religious matters sometimes I tend to mix Tamil with English. It becomes almost natural".

A sharp shift can be observed among younger Tamils of the 12-21 year age cohort who tend to use standalone English (68.2\%) and a mixture of Tamil and English $(27.3 \%)$ when reading religious books. Respondent 22 (male, 19 years old) stated: "I can't read in Tamil, only in English and Bahasa Melayu. I seldom buy religious books. I learned the prayers by heart in Tamil".

However, for older age cohorts of 22-39 and 40-59 years, $41.3 \%$ and $51.7 \%$, respectively, still read religious books in the Tamil language. All of the respondents 
aged 60 and above only read religious books in Tamil. However, of those aged $40-59,41.4 \%$ prefer to read religious books in a mixture of Tamil and English. Most members of the older age cohorts of 22-39 and 40-59 years use Tamil to pray compared to $50 \%$ of the respondents of the 12-21 year age cohort. Respondent 9 (male, 14 years old) stated: "I pray in Tamil because my God is Tamil and understands only Tamil". The remaining $13.6 \%$ of the respondents of the same age cohort code-switched using more Tamil with less English, and 36.4\% use standalone English when praying silently.

All of the respondents of 60 years of age and above, and $93.1 \%$ of those of the 40-59 year age cohort use standalone Tamil when speaking with temple priests. However, $3.4 \%$ of the respondents of the $40-59$ year age cohort use either standalone Bahasa Melayu or English when speaking to a temple priest. Respondent 33 (male, 44 years old) stated: "I mix Tamil with English and a few words of Malay especially for certain common items such as Malay food and festivals when discussing certain matters with the priest. Even though he's from India, he understands them because these are local expressions and he has been here for some years now".

Although the majority (90.5\%) of the 22-39 year age cohort uses Tamil with priests, the percentage is lower for those of the 12-21 year age cohort with only 63.6\% speaking Tamil with temple priests and with 36.4\% using English when speaking with priests. Respondent 27 (female, 17 years old) stated: "The priest speaks good English. He comes from India. He doesn't mind me speaking in English with him".

All of the respondents of 60 years and above prefer to participate in religious activities conducted in Tamil and $93.1 \%$ of those of the 40-59 year age cohort felt the same way. The remaining $6.9 \%$ of the respondents of the $40-59$ year age cohort use English when participating in religious activities.

A total of $84.1 \%$ of the respondents of the 22-39 year age cohort prefer to use Tamil and $4.8 \%$ code-switched to a pattern of more Tamil with less English when participating in religious activities. However, only $45.5 \%$ of the respondents of the 12-21 year age cohort use standalone Tamil when participating in religious groups. A total of $36.4 \%$ of the respondents of the 12-21 year age cohort prefer to participate in religious activities conducted in English. Approximately 4.5\% of those of the 12-21 year age cohort use standalone Bahasa Melayu and 13.6\% code-switched to a pattern of more Tamil with less English when participating in religious activities. 


\section{Language with friends}

Similar shifts appear in this particular setting (see Appendix - Table E). In total, $45.5 \%$ of the respondents of the 12-21 year age cohort use a mixture of Tamil and English when sending voicemails via mobile phones, and $36.4 \%$ of the respondents of the 12-21 year age cohort report that they use standalone English when sending voicemails via mobile phones. Saravanan (1998) studied the network patterns of bilingual Chinese, Malay and Tamil children in Singapore and found a shift in language use patterns from use of the community language to the use of English during peer interactions. Only $18.2 \%$ of the respondents of this age group use Tamil when sending voicemails via mobile phones. Respondent 19 (male, 20 years old) stated: "I mix Tamil with English more often than my parents. I realise that. Maybe it is because that's the style my friends are using nowadays".

As for the respondents of the 22-39 year age cohort, a large minority, $46.0 \%$ use Tamil when sending voicemails via mobile phones. Another $42.9 \%$ use a mixture of Tamil with English when sending voicemails via mobile phones. Most (82.8\%) respondents of the 40-59 year age group use Tamil when sending voicemails via mobile phones. Respondent 36 (male, 43 years old) stated: "I speak more Tamil, in fact only Tamil because I cannot really speak English". All respondents of 60 years of age and above use Tamil when sending voicemails.

When asking for favours or making requests from Tamil friends, most (45.5\%) respondents of the 12-21 year age cohort stated they use more Tamil and less English. Respondent 12 (male, 17 years old) stated: "I speak Tamil when asking for favours from older friends. They like it. It's a sign of respect". Another $36.4 \%$ stated they use standalone English for the same speech act. Only $18.2 \%$ of the 12-21 year age cohort stated that they use only Tamil when asking for favours.

A total of $47.6 \%$ of the respondents of the 22-39 year age cohort stated they use standalone Tamil while $41.3 \%$ use a mixture of more Tamil with less English for this same speech act. A large majority or $86.2 \%$ of the respondents of the 40-59 year age cohort and all of the respondents of 60 years and above use standalone Tamil when asking friends for favours.

Generally, the respondents of all age groups are of the view that Tamil is the best language to use to gain respect, though the percentage declines with a decrease in age (see Appendix - Table E). While $54.5 \%$ of the respondents of the 12-21 year age cohort use Tamil for this purpose, another $45.5 \%$ use English. On the other hand, $82.5 \%$ of the respondents of the $22-39$ year age cohort, $93.1 \%$ of the respondents of the 40-59 year age cohort and $100 \%$ of the respondents of 60 years 
and above stated that they use standalone Tamil to gain respect. Respondent 60 (male, 59 years old) stated: "Speak Tamil to Tamil people to show and gain respect. The younger people have lost this, a real tragedy!"

Approximately $45.5 \%$ of the respondents of the 12-21 year age cohort use English when greeting Tamils, $31.8 \%$ use a mixture of Tamil and English, and $18.2 \%$ greet Tamils in their heritage language. Most of those of the 22-39 year, 40-59 year, and 60 year and above age cohorts use standalone Tamil to greet other Tamils. In total, $34.9 \%$ of the respondents of the 22-39 year age cohort use a mixture of Tamil and English and 12.7\% tend to use standalone English whereas $79.3 \%$ of those of the 40-49 year age cohort use standalone Tamil when greeting other Tamils while $6.9 \%$ of them use a mixture of Tamil and English.

Despite the obvious shift away from the use of Tamil language in the younger age group, in this particular setting, Tamil is the language of choice for $59.1 \%$ of the respondents of the age 12-21 year age cohort when purchasing products from Tamil shopkeepers, with 36.4\% using Bahasa Melayu.

Respondent 27 (female, 24 years old) stated: "When I go to the market with my mother, I speak in Tamil to the people in the Indian shop. They speak in Tamil with my mother. I don't want to appear snobbish". A total of $77.8 \%$ and $82.8 \%$ of the respondents of the 22-39 and 40-59 year age cohorts, respectively, stated that they use standalone Tamil for such transactions. All respondents of 60 years and above stated they use only Tamil in such settings.

\section{Discussion}

Before coming to any conclusion on language shifts among the Tamils in Kuching, it is important to compare results of the analysis on age cohorts with language choices made in different domains - the home, temples and social settings. Changes observed in patterns of language choice among the younger cohorts may not necessarily differ from those of the older cohorts. Mukherjee $(2011,266)$ noted that:

Difference between the age groups in their language use patterns may reflect radically different causes depending whether these are new developments not experienced by earlier age cohorts when they were at that age (in which case genuine sociolinguistic change exists) or, merely a pattern of age-related changes which are experienced by the previous cohorts as they went through the life cycle as different linguistic behaviour is expected of the people at different ages. 
There have been changes in patterns of language used by the 12-21 year age cohort and those aged 60 years and above. The use of Tamil in the home domain shows a drop from the use of $100 \%$ standalone Tamil for those 60 years and above to the use of a mixed code pattern of Tamil with code-switches of English and Bahasa Melayu for the 12-21 year age cohort. Among the younger age cohorts there has been an increase in the use of English in the home domain. For the 40-59 year age cohort, the drop in the use of Tamil is less significant than the increase in the use of English in the home domain. This finding suggests that those who are 40 years of age and above are still maintaining the use of Tamil in the home domain. It is possible that language practices of the younger cohorts in the home domain have been shaped by sociolinguistic environments in schools and by the increasing globalisation of the English language in the realms of media and technology.

The English language features more prominently in the lives of the 12-21 and 22-39 year age cohorts in all domains relative to respondents of 40 years of age and above. Globalisation and the increasing importance of English appear to have led parents who are able to speak English to believe that if their children were to learn and speak only Tamil at home, this would hinder their progress in learning English and would thus compromise their access to scholarships, higher education overseas and job opportunities in the private sector. This situation is reflected in the use of English by individuals of younger cohorts with their parents at home. Generally, English has become a language of communication for the younger age cohorts and even in the social and temple domains although not entirely as a standalone language. This in turn has led to the development of a communication gap between those of the 12-21 year age group and those aged 60 and above who speak standalone Tamil and Bahasa Melayu only. Many of the respondents of both age cohorts reported that the communication gap is felt more by their grandparents of the 60 years and above age cohort. Respondent 23, a 61-year-old, stated: "Sometimes I do feel left out when speaking with family members. They use Malay, English and Tamil and mix them. I can't do the same as I speak only Tamil".

Having been brought up in a multiracial environment such as their parents and grandparents, those of the 12-21 and 22-39 year age cohorts have been heavily influenced by social media and by Malaysia's language policies and education system. The older age cohorts view this trend as alarming and as a threat to Tamil cultural identity, and so they insist on the use of other cultural markers of identity to reflect their Tamil-ness. Many older Tamils are now insisting that their children marry within the community to prevent total language loss. As respondent 39 (female, 49 years old) stated: "I want my boys to marry Tamil girls from the 
peninsula or better still from Madras, as we still have relatives there. I want their families to speak Tamil at home". Efforts such as this one are attempts to revitalise the use of the heritage language within the minority community in Kuching.

Language is only one marker of identity and members of the younger generation assert their ethnic identity and claim that they are Tamils because they eat Tamil food, listen to Tamil music, and appreciate Tamil dances and movies. In addition, they frequent the Hindu temples and community gathering centres, irrespective of what language they choose to speak with one another.

\section{Conclusion}

Although the Kuching Tamils maintain close networks, are related to one another, live close to each other and share the same religion, such social networks by themselves do not result in language maintenance. As the descendants of the early Tamils become more educated and sophisticated, there is a strong tendency to speak English more often at home. English is regarded by the younger group of Tamils as an international language that has more economic value than Tamil or Malay, and it is viewed as a form of social capital that can provide their small community both local and international mobility. In fact, Saravanan (1998) makes an interesting observation of the Tamil community in Singapore that is also emerging from the Kuching data and findings. It is Saravanan's opinion that the maintenance of the Tamil language in Singapore is very poor and must be strengthened. In fact, the community is referred to as a Tamil-English community rather than as a Tamil community.

\section{Limitations of the Study}

Needless to say, this study presents methodological limitations. First, a snowball sampling technique was used to identify respondents, and the first set of respondents was met at a Hindu function held at a temple. After each interview, respondents were asked to provide the names of relatives or friends who would be willing to be interviewed. As such, respondents may be of the same socio-economic background, potentially rendering the sample susceptible to bias. The sample may not reflect all Indians in Sarawak, Malaysia, and thus, the study's generalisability is limited. Second, we employ a cross-sectional design, as the timing of the snapshot used may or may not be guaranteed to be representative. Third, as data were "selfreported", other forms of bias may have applied, and thus, future studies may use participant or non-participant observation methods to further validate our findings. 


\section{Acknowledgement}

The authors would like to thank University of Malaya for funding this research. This research was supported by the University of Malaya Research Grant (UMRG) under grant number RG091/11SBS.

\section{Appendix}

Table A. Language first learnt

\begin{tabular}{lcccc}
\hline \multirow{2}{*}{ Language first learnt Age groups \% } \\
\cline { 2 - 5 } & $\mathbf{1 2 - 2 1}$ & $\mathbf{2 2 - 3 9}$ & $\mathbf{4 0 - 5 9}$ & $+\mathbf{6 0}$ \\
\hline Tamil & 63.6 & 92.1 & 93.1 & 100 \\
Bahasa Melayu & - & 1.6 & 6.9 & - \\
English & 36.4 & 6.3 & - & - \\
\hline
\end{tabular}

Table B. Language in the home domain

\begin{tabular}{lcccc}
\hline \multirow{2}{*}{ Language used with } & \multicolumn{5}{c}{ Age groups \% } \\
\cline { 2 - 5 } & $\mathbf{1 2 - 2 1}$ & $\mathbf{2 2 - 3 9}$ & $\mathbf{4 0 - 5 9}$ & $\mathbf{+ 6 0}$ \\
\hline Grandmother & 63.6 & 92.1 & 93.1 & 100 \\
$\quad$ Tamil & 36.4 & 7.9 & 6.9 & - \\
Bahasa Melayu & - & - & - & - \\
English & - & - & - & - \\
Other Indian languages & - & - & - & - \\
Mix-Tamil \& Bahasa Melayu & - & - & - & - \\
Mix-Tamil \& English & & & & \\
Grandfather & 63.6 & 92.1 & 93.1 & 100 \\
Tamil & 36.4 & 7.9 & 6.9 & - \\
Bahasa Melayu & - & - & - & - \\
English & - & - & - & - \\
Other Indian languages & - & - & - & - \\
Mix-Tamil \& Bahasa Melayu & - & - & - & - \\
Mix-Tamil \& English & & & & \\
Mother & 40.9 & 57.1 & 93.1 & 100 \\
Tamil & 4.5 & 1.6 & 5.9 & - \\
Bahasa Melayu & 35.4 & 9.5 & - & - \\
English & 4.5 & - & - & - \\
Other Indian languages & - & 3.2 & - & - \\
Mix-Tamil \& Bahasa Melayu & 14.7 & 28.6 & - & - \\
Mix-Tamil \& English & & & - \\
\hline
\end{tabular}


Table B. (Continued)

\begin{tabular}{lcccc}
\hline \multirow{2}{*}{ Language used with } & \multicolumn{5}{c}{ Age groups \% } \\
\cline { 2 - 5 } & $\mathbf{1 2 - 2 1}$ & $\mathbf{2 2 - 3 9}$ & $\mathbf{4 0 - 5 9}$ & $\mathbf{+ 6 0}$ \\
\hline Father & 27.3 & 49.2 & 85.2 & 100 \\
$\quad$ Tamil & - & 1.6 & 6.9 & - \\
$\quad$ Bahasa Melayu & 45.5 & 11.1 & - & - \\
English & - & - & - & - \\
Other Indian languages & - & 4.8 & - & - \\
Mix-Tamil \& Bahasa Melayu & 27.3 & 33.3 & 6.9 & - \\
$\quad$ Mix-Tamil \& English & & & & \\
Older siblings & - & 38.1 & 86.2 & 100 \\
$\quad$ Tamil & - & 1.6 & 6.9 & - \\
Bahasa Melayu & 50.1 & 11.1 & - & - \\
English & - & - & - & - \\
Other Indian languages & 13.6 & - & - & - \\
Mix-Tamil \& Bahasa Melayu & 36.4 & 49.2 & 6.9 & - \\
$\quad$ Mix-Tamil \& English & & & & \\
Younger siblings & - & 38.1 & 82.8 & 100 \\
Tamil & 4.5 & 1.6 & 6.9 & - \\
Bahasa Melayu & 45.5 & 11.1 & - & - \\
English & - & - & - & - \\
Other Indian languages & 13.6 & - & - & - \\
Mix-Tamil \& Bahasa Melayu & 36.4 & 49.2 & 10.3 & - \\
Mix-Tamil \& English & & & & \\
\hline
\end{tabular}

Table C. Language with visitors

\begin{tabular}{lcccc}
\hline \multirow{2}{*}{ Language used with } & \multicolumn{5}{c}{ Age groups \% } \\
\cline { 2 - 5 } & $\mathbf{1 2 - 2 1}$ & $\mathbf{2 2 - 3 9}$ & $\mathbf{4 0 - 5 9}$ & $\mathbf{+ 6 0}$ \\
\hline Tamil visitors & 4.5 & 44.4 & 82.8 & 100 \\
$\quad$ Tamil & - & 1.6 & - & - \\
$\quad$ Bahasa Melayu & 36.4 & 6.3 & 6.9 & - \\
$\quad$ English & - & - & - & - \\
$\quad$ Other Indian languages & - & - & - & - \\
$\quad$ Mix-Tamil \& Bahasa Melayu & 59.1 & 47.6 & 10.3 & - \\
$\quad$ Mix-Tamil \& English & & &
\end{tabular}


Table C. (Continued)

\begin{tabular}{lcccc}
\hline \multirow{2}{*}{ Language used with } & \multicolumn{4}{c}{ Age groups \% } \\
\cline { 2 - 5 } & $\mathbf{1 2 - 2 1}$ & $\mathbf{2 2 - 3 9}$ & $\mathbf{4 0 - 5 9}$ & $\mathbf{+ 6 0}$ \\
\hline $\begin{array}{l}\text { Malayalees \& Telegu visitors } \\
\text { Tamil }\end{array}$ & 4.5 & 39.7 & 34.5 & - \\
$\quad$ Bahasa Melayu & - & - & - & - \\
English & 63.6 & 34.9 & 17.2 & - \\
$\quad$ Other Indian languages & - & - & - & - \\
$\quad$ Mix-Tamil \& Bahasa Melayu & - & 4.8 & 10.3 & - \\
$\quad$ Mix-Tamil \& English & 31.8 & 20.6 & 37.9 & 100 \\
\hline
\end{tabular}

Table D. Language in the religious domain

\begin{tabular}{lcccc}
\hline \multirow{2}{*}{ Interaction in temple: Language used } & \multicolumn{5}{c}{ Age groups \% } \\
\cline { 2 - 6 } & $\mathbf{1 2 - 2 1}$ & $\mathbf{2 2 - 3 9}$ & $\mathbf{4 0 - 5 9}$ & $\mathbf{+ 6 0}$ \\
\hline With Tamils of the same age & & & & \\
$\quad$ Tamil & 13.6 & 55.6 & 89.7 & 100 \\
$\quad$ Bahasa Melayu & - & 3.2 & 6.9 & - \\
English & 36.4 & 6.3 & - & - \\
Other Indian languages & - & - & - & - \\
Mix-Tamil \& Bahasa Melayu & 4.5 & 6.3 & - & - \\
Mix-Tamil \& English & 45.5 & 28.6 & 3.4 & - \\
With Tamils of other age & & & & \\
Tamils & 27.3 & 31.7 & 69.0 & - \\
Bahasa Melayu & - & 1.6 & 6.9 & - \\
English & 35.3 & 9.5 & - & - \\
Other Indian languages & - & - & - & - \\
Mix-Tamil \& Bahasa Melayu & - & 9.5 & 3.4 & 100 \\
Mix-Tamil \& English & 37.4 & 47.6 & 20.7 & - \\
When discussing religious matters & & & & \\
Tamil & 45.5 & 85.7 & 93.1 & 100 \\
Bahasa Melayu & 4.5 & 3.2 & 3.4 & - \\
English & 36.4 & 6.3 & 3.4 & - \\
Other Indian languages & - & - & - & - \\
Mix-Tamil \& Bahasa Melayu & - & - & - & - \\
Mix-Tamil \& English & 13.6 & 4.8 & - & - \\
\hline
\end{tabular}


Table D. (Continued)

\begin{tabular}{|c|c|c|c|c|}
\hline \multirow{2}{*}{ Interaction in temple: Language used } & \multicolumn{4}{|c|}{ Age groups \% } \\
\hline & $12-21$ & 22-39 & $40-59$ & +60 \\
\hline \multicolumn{5}{|l|}{ When reading religious books } \\
\hline Tamil & - & 41.3 & 51.7 & - \\
\hline Bahasa Melayu & 4.5 & 1.6 & - & - \\
\hline English & 68.2 & 31.7 & 6.9 & - \\
\hline Other Indian languages & - & - & - & - \\
\hline Mix-Tamil \& Bahasa Melayu & - & - & - & - \\
\hline Mix-Tamil \& English & 27.3 & 25.4 & 41.4 & 100 \\
\hline \multicolumn{5}{|l|}{ When praying silently } \\
\hline Tamil & 50.0 & 87.3 & 93.1 & 100 \\
\hline Bahasa Melayu & - & 1.6 & 3.4 & - \\
\hline English & 36.4 & 6.3 & 3.4 & - \\
\hline Other Indian languages & - & - & - & - \\
\hline Mix-Tamil \& Bahasa Melayu & - & - & - & - \\
\hline Mix-Tamil \& English & 13.6 & 4.8 & - & - \\
\hline \multicolumn{5}{|l|}{ When talking to priest } \\
\hline Tamil & 63.6 & 90.5 & 93.1 & 100 \\
\hline Bahasa Melayu & - & 3.2 & 3.4 & - \\
\hline English & 36.4 & 6.3 & 3.4 & - \\
\hline Other Indian languages & - & - & - & - \\
\hline Mix-Tamil \& Bahasa Melayu & - & - & - & - \\
\hline Mix-Tamil \& English & - & - & - & - \\
\hline \multicolumn{5}{|c|}{ Preference to join religious activities conducted using } \\
\hline Tamil & 45.5 & 84.1 & 93.1 & 100 \\
\hline Bahasa Melayu & 4.5 & 3.2 & - & - \\
\hline English & 36.4 & 7.9 & 6.9 & - \\
\hline Other Indian languages & - & - & - & - \\
\hline Mix-Tamil \& Bahasa Melayu & - & - & - & - \\
\hline Mix-Tamil \& English & 13.6 & 4.8 & - & - \\
\hline
\end{tabular}


Table E. Language with friends

\begin{tabular}{|c|c|c|c|c|}
\hline \multirow{2}{*}{ Language use when } & \multicolumn{4}{|c|}{ Age groups \% } \\
\hline & $12-21$ & 22-39 & $40-59$ & +60 \\
\hline \multicolumn{5}{|l|}{ Sending voicemail via mobile phone } \\
\hline Tamil & 18.2 & 46.0 & 82.8 & 100 \\
\hline Bahasa Melayu & - & 1.6 & 6.9 & - \\
\hline English & 36.4 & 9.5 & - & - \\
\hline Other Indian languages & - & - & - & - \\
\hline Mix-Tamil \& Bahasa Melayu & - & - & - & - \\
\hline Mix-Tamil \& English & 45.5 & 42.9 & 10.3 & - \\
\hline \multicolumn{5}{|l|}{ Asking favour from Tamil relatives } \\
\hline Tamil & 18.2 & 47.6 & 86.2 & 100 \\
\hline Bahasa Melayu & - & 1.6 & 6.9 & - \\
\hline English & 36.4 & 9.5 & - & - \\
\hline Other Indian languages & - & - & - & - \\
\hline Mix-Tamil \& Bahasa Melayu & - & - & - & - \\
\hline Mix-Tamil \& English & 45.5 & 41.3 & 6.9 & - \\
\hline \multicolumn{5}{|l|}{ To win respect of Tamils } \\
\hline Tamil & 54.5 & 85.7 & 93.1 & 100 \\
\hline Bahasa Melayu & - & 1.6 & 6.9 & - \\
\hline English & 45.5 & 9.5 & - & - \\
\hline Other Indian languages & - & - & - & - \\
\hline Mix-Tamil \& Bahasa Melayu & - & - & - & - \\
\hline Mix-Tamil \& English & - & 3.2 & - & - \\
\hline \multicolumn{5}{|l|}{ When greeting Tamils } \\
\hline Tamil & 18.2 & 47.6 & 79.3 & 100 \\
\hline Bahasa Melayu & 4.5 & 3.2 & 13.8 & - \\
\hline English & 45.5 & 12.7 & - & - \\
\hline Other Indian languages & - & - & - & - \\
\hline Mix-Tamil \& Bahasa Melayu & - & 1.6 & - & - \\
\hline Mix-Tamil \& English & 31.8 & 34.9 & 6.9 & - \\
\hline \multicolumn{5}{|c|}{ Buying spices from Tamil shopkeeper } \\
\hline Tamil & 59.1 & 77.8 & 82.8 & 100 \\
\hline Bahasa Melayu & 36.4 & 15.9 & 6.9 & - \\
\hline English & 4.5 & 1.6 & - & - \\
\hline Other Indian languages & - & - & - & - \\
\hline Mix-Tamil \& Bahasa Melayu & - & 4.8 & 6.9 & - \\
\hline Mix-Tamil \& English & - & - & 3.4 & - \\
\hline
\end{tabular}




\section{References}

Audrey, W. 2008. The minority Kuching Hindus celebrates Deepavali. Borneo Post (14 October): 16.

Chang, P.F. 2002. History of Bidayuh in Kuching Division Sarawak. Kuching: Lee Ming Press Co.

Clyne, M. 1976. Australia Talks: Essays on Australian immigrant and aboriginals languages. Canberra: Department of Linguistics, Australian National University.

David, M.K. 1999. Language shift amongst the Sindhis of Malaysia. South Pacific Journal of Psychology (Special Issue: Asia-Pacific Language Research) 10(1): 61-67. https://doi.org/10.1017/S0257543400001012

2001. The Sindhis of Malaysia: A sociolinguistic account. London: Asean Academic Press.

2003. Language maintenance or language shift in a rural Malaysian setting? Urdu in Machang, Kelantan. International Journal of the Sociology of Language 161: 47-54.

2005. The network theory and language maintenance: A study of three communities in Peninsular Malaysia. In Creating outsiders: Endangered languages, migration and marginalization, eds. N. Crawhall and N. Ostler, 153-157. Bath: Foundation for Endangered Languages.

. 2006. Language choices and discourse of Malaysian families: Case studies of families in Kuala Lumpur, Malaysia. Petaling Jaya: Strategic Information and Research Development Centre (SIRD).

. 2009. The importance of a historical perspective in language shift studies: Focus on minority groups in Kuching. Paper presented at the Indian Cultural Seminar, 29 March 2009, Kuching, Sarawak, Malaysia.

David, M.K. and Dealwis, C. 2006. Close and dense networks: Do they lead to maintenance of the ethnic language? Focus on the Telegu community in Kuching, Sarawak. Migracijske i etničke teme (Migration and Ethnic Themes) 22(4): 343-361. .2009. Reasons for assimilation: Focus on the Indian Muslims in Kuching, Malaysia. Migracijske i etničke teme (Migration and Ethnic Themes) 25(1-2): 35-48.

David, M.K. and Noor, F. 1999. Language maintenance or language shift in the Portuguese Settlement of Malacca in Malaysia? Migracijske $i$ etničke teme (Migration and Ethnic Themes) 15(4): 465-481.

David, M.K., Abdullah, A., Rafik-Galea, S. and Mclellan, J. 2009. Code switching in Malaysia. Frankfurt: Peter Lang.

David, M.K., Dealwis, C. and Alagappar, P.N. 2011. Ethnic identity in the Tamil community of Kuching. In National language planning and language shifts in Malaysian minority communities: Speaking in many tongues (IIAS/ICAS Publications Series), eds. D. Mukherjee and M.K. David, 43-58. Amsterdam: University of Amsterdam Press.

David, M.K., Naji, I. and Kaur, S. 2003. Language maintenance or language shift among the Punjabi Sikh community in the Klang Valley, Malaysia? International Journal of the Sociology of Language 161: 1-24. https://doi.org/10.1515/ijsl.2003.026 
Dealwis, C. and David, M.K. 2010. In search of an identity: Children of Indian-Bidayuh mixed marriages. In Ethnic relations and nation building, eds. M.K. David et al., 145-162. Petaling Jaya: Strategic Information and Research Development Centre (SIRD).

Demos, V. 1988. Ethnic mother-tongue maintenance among Greek Orthodox Americans. International Journal of the Sociology of Language 69: 9-72. https://doi. org/10.1515/ijsl.1988.69.59

Department of Statistics Malaysia. 2009. Monthly Statistical Bulletin Sarawak, June 2009. Sarawak: Percetakan Nasional Malaysia Berhad.

Downes, W. 1984. Language and society. London: Fontana.

Emerson, R. 1973. Malaysia: A study in direct and indirect rule. London: Macmillan.

Fasold, R. 1984. The sociolinguistics of society. Oxford: Blackwell.

Ferguson, C.A. 1959. Diglossia. Word 15: 325-340. https://doi.org/10.1080/00437956.19 59.11659702

Fishman, J.A. 1972. The sociology of language. Newbury: Rowley.

Gal, S. 1979. Language shift: Social determinants of language change in bilingual Austria. New York: Academic Press.

Govindasamy, M. and Nambiar, M. 2002. Social networks: Applicability to minority communities in multilingual settings. International Journal of the Sociology of Language 161: 25-45.

Gumperz, J. 1982. Discourse strategies. New York: Cambridge University Press. https://doi.org/10.1017/CBO9780511611834

Heller, M. 1988. Code-switching: Anthropological and sociolinguistic perspectives. Berlin: Mouton de Gruyter. https://doi.org/10.1515/9783110849615

Lieberson, S. 1965. Bilingualism in Montreal: A demographic analysis. American Journal of Sociology 71(1): 10-25. https://doi.org/10.1086/223989

Mills, L.A. 1941. British rule in Eastern Asia. New York: Russell \& Russell.

Milroy, L. 1980. Language and social networks. Oxford: Blackwell. 1987. Observing and analyzing natural language. Oxford: Blackwell.

Mukherjee, D. 2003. Role of women in language maintenance and language shift: Focus on the Bengali community in Malaysia. International Journal of the Sociology of Language 161: 103-120.

Mukherjee, D. and David, M.K. (eds.). 2011. National language planning and language shifts in Malaysian minority communities: Speaking in many tongues. Amsterdam: Amsterdam University Press.

Nambiar, M.K. 2007. Language shift in the Malayalee community: A study of intra group variations. $\mathrm{PhD}$ dissertation, University of Malaya, Malaysia.

Sankar, L.V. 2004. Language shift and maintenance among the Malaysian Iyer. PhD dissertation, University of Malaya, Malaysia.

Saravanan, V. 1998. Language maintenance and language shift in the Tamil community. In Language society and education in Singapore, ed. S. Gopinathan, 155-176. Singapore: Times Academic Press. 
Saxena, M. 2003. Investigating language maintenance and shift among non-indigenous minorities: Age-grading and or age-cohort analysis. In Methodological and analytical issues in language maintenance and shift studies, ed. M.K. David, 121143. Frankfurt: Peter Lang.

Tate, M.D. 2008. The Malaysian Indians: History, problems and future. Petaling Jaya: Strategic Information and Research Development Centre (SIRD).

Wallwork, J.F. 1978. Language and people. London: Heinemann Educational Books. 